\title{
UPAYA PEMBERDAYAAN MASYARAKAT MELALUI REFUNGSI JAMBAN KOLAM LELE MENJADI JAMBAN SEHAT DALAM RANGKA MENUJU DESA ODF (OPEN DEFECATION FREE)
}

\author{
Community Empowering Through The Refunction of Jamban Kolam Lele \\ Into Healthy Fungus In Order To Become \\ The ODF Village (Open Defecation Free)
}

\author{
Nurul Hidayah ${ }^{1}$, Marwan ${ }^{2}$ \\ 1,2 Akademi Keperawatan Pemerintah Kabupaten Ngawi \\ Jl. Dr. Wahidin No 49 Ngawi 63212 Telp. (0351) 744859 \\ email: nurulridlo@gmail.com
}

\begin{abstract}
ABSTRAK
Salah satu fasilitas sanitasi dasar yang wajib dimiliki warga adalah jamban keluarga, sebagai tempat membuang kotoran manusia. Akan tetapi masih banyak warga yang belum memiliki jamban dan mempunyai kebiasaan $\mathrm{BAB}$ disembarang tempat salah satunya di kolam lele. Perilaku warga ini berisiko menularkan penyakit berbasis lingkungan, seperti: diare, cholera, cacing, thypoid, parathypoid, hepatitis, malnutrisi, pencemaran air dan mengurangi estetika.

Tujuan pengabdian masyarakat ini adalah melakukan refungsi jamban kolam lele menjadi jamban sehat sederhana dalam rangka menuju desa ODF. Populasi target pada pengabdian masyarakat ini adalah warga Dusun Gebang Sewu yang masih BAB di kolam lele sebanyak 42 KK. Metode yang digunakan adalah pemberdayaan masyarakat melalui kegiatan, penyuluhan, pemberian teknik stimulan jamban, penentuan kebijakan sosial tentang ODF melalui PERDES, pembentukan kader STBM, dan pelatihan proses pembibitan lele.

Setelah dilakukan kegiatan pengabdian masyarakat berupa penyuluhan STOP BABs pengetahuan masyarakat tentang risiko BABs dan mnfaat jamban sehat meningkat, yang dibuktikan dengan adanya 23 KK yang menghadiri penyuluhan bersedia merefungsi jamban kolam lelenya menjadi jamban sehat sederhana dengan konsep stimulan dan 19 KK lainnya belum bersedia. Sudah ditetapkan PERDES tentang ODF oleh kepala Desa setempat dan terbentuk kader cilik STBM.

ODF merupakan masalah sanitasi lingkungan yang masih perlu mendapatkan perhatian dari semua pihak termasuk dari praktisi akademis dan pelayanan masyarakat, serta indikator keberhasilannya dapat dicapai melalui upaya pemberdayaan masyarakat
\end{abstract}

Kata Kunci: BAB disembarang tempat, $O D F$, Jamban di kolam lele

\section{PENDAHULUAN}

Salah satu upaya kesehatan yang dilakukan di masyarakat adalah penyediaan fasilitas sanitasi dasar berupa jamban. Jamban berguna untuk membuang kotoran manusia sehingga bakteri dalam kotoran manusia tidak mencemari lingkungan. Jamban keluarga adalah suatu tempat yang digunakan untuk membuang kotoran anggota keluarga yang lazim disebut dengan WC/ Kakus. Bagi keluarga yang belum memiliki jamban, hampir dapat dipastikan mereka akan memanfaatkan sungai, parit, kebun, semaksemak, kolam atau tempat lainnya untuk buang air besar (BAB) (Pebriani, 2015).
Dengan masih adanya kebiasaan masyarakat $\mathrm{BAB}$ disembarang tempat, maka wilayah tersebut terancam penyakit berbasis lingkungan, seperti: diare, cholera, cacing, thypoid, parathypoid, hepatitis A dan E, malnutrisi dan penyakit lainnya (Mukherjee, 2011). Selain itu kebiasaan BAB disembarang tempat dapat menimbulkan pencemaran air, bau busuk dan mengurangi estetika. Semakin besar prosentase masyarakat yang $\mathrm{BAB}$ di sembarang tempat, maka ancaman penyakit berbasis lingkungan juga semakin besar. Masalah kesehatan lingkungan muncul akibat rendahnya kesadaran masyarakat tentang sanitasi lingkungan. Kondisi ini seperti boom 
waktu yang suatu saat bisa terjadi ledakan penyakit akibat lingkungan yang kurang bersih. Sebaliknya apabila setiap keluarga memiliki jamban sehat dan terbiasa $\mathrm{BAB}$ dijamban, maka wilayahnya terbebas dari ancaman penyakit berbasis lingkungan (Pebriani, 2015).

Kebiasaan BAB disembarang tempat masih menjadi kebiasaan masyarakat diseluruh dunia, bahkan setiap tahun terdapat lebih dari 1 juta orang $\mathrm{BAB}$ disembarang tempat (United Nation, 2015). Di Afrika terdapat 215 warga masih $\mathrm{BAB}$ disembarang tempat, bahkan hanya $10 \%$ wilayah afrika yang mengalami penurunan kebiasaan $\mathrm{BAB}$ disembarang yaitu ethiopia, dan angola (Galan, 2013). Hal serupa juga terjadi di Kenya, dimana 5,6 juta warganya BAB disembarang tempat. Bahkan setiap tahunnya sekitar 17.100 anak di Kenya meninggal karena penyakit diare, yang diakibatkan karena kebiasaan B AB s (Water and sanitation program, 2014). BABs juga berisiko menularkan penyakit kecacingan dan gangguan penyerapan usus yang sering dikaitkan dengan kondisi stunting pada anak (Humphrey, 2009). Demikian juga di India, $10 \%$ kasus stunting disebabkan oleh BABs, dan $54 \%$ terjadi pada masyarakat msikin dan $65 \%$ masyarakat yang tinggal di perkampungan padat (Spears D, 2013).

Di Indonesia, prevalensi penyakit berbasis lingkungan masih cukup tinggi, yaitu diare $72 \%$, kecacingan $0,85 \%$, scabies $23 \%$, trakhoma $0,14 \%$, hepatitisA $0,57 \%$, hepatitis E $0,02 \%$ dan malnutrisi 2,5\% (WSPEAP,2008). Penyebab penyakit berbasis lingkungan adalah bakteri, virus, parasit dan jamur (Kandun, 2006; Bannister 2006). Proses transmisinya melalui " $4 \mathrm{~F}$ " yaitu Fluids, Fields, Flies dan Fingers. Siklus ini dimulai dari kontaminasi tinja manusia melalui pencemaran air dan tanah, penyebaran serangga dan tangan kotor yang dipindahkan ke makanan sehingga dikonsumsi oleh manusia atau fecal-oral transmission. Proses penularan penyakit tersebut dipengaruhi oleh karakteristik penjamu (imunitas, status gizi, status kesehatan, usia dan jenis kelamin) dan perilaku penjamu (kebersihan diri dan kebersihan makanan) (Carr, 2001; Cairncross, 2006).

Berdasarkan hasil survey pendahuluan yang dilakukan pada tanggal 16 April 2018, dari 217 rumah di Dusun Gebang Sewu terdapat 42 rumah yang memiliki jamban dengan septictank sebanyak 145 rumah, jamban cemplung 22 rumah, numpang di tempat tetangga 6 rumah, disungai 2 rumah, dan jamban di kolam lele sebanyak 42 rumah. Dengan kebiasaan masyarakat tersebut bukan tidak mungkin suatu saat masyarakat diwilayah ini akan terancam penyakit menular yang berbasis lingkungan. Data prevalensi penyakit berbasis lingkungan dari wilayah kerja puskesmas Teguhan sejak bulan Januari sampai dengan maret 2018 adalah: diare 50 kasus, tifhoid 30 kasus, hepatits 20 kasus, gizi buruk 6 kasus. Tingginya angka pertumbuhan penduduk, rendahnya pendapatan dan kurangnya pengetahuan masyarakat tentang jamban sehat menyebabkan semakin rumitnya masalah jamban di Dusun ini. Ada beberapa faktor yang menyebabkan masyarakat untuk menggunakan kolam lele sebagai saptiktank dari jamban. Masyarakat beranggapan bisa menekan pembiayaan pakan lele, tidak perlu menguras saptiktank, dan lelenya dijual tidak dikonsumsi sendiri. Dari study pendahuluan juga diketahui masyarakat belum tahu bahaya dari lele yang diternak dengan media jamban.

Salah satu upaya program pemerintah untuk mengatasi masalah BAB adalah STBM (Sanitasi Total Berbasis Masyarakat). Program ini bertujuan untuk mendapatkan pendekatan yang optimal dalam pembangunan sanitasi di pedesaan, dengan pendekatan program berupa pemberdayaan atau metode pemicuan. Hasil akhirnya perubahan cara pandang dan perilaku sanitasi masyarakat untuk berinisiatif membangun jamban sendiri tanpa subsidi pihak luar. BABS adalah masalah bersama karena berimplikasi kepada semua masyarakat sehingga pemecahannya juga harus dilakukan dan dipecahkan secara bersama.(Kamal, 2008; ditjen PP-PL,2008). Demikian juga di Dusun Gebang Sewu yang belum dinyatakan ODF, untuk mengatasi masalah didusun tersebut dilakukan dengan pemberdayaan masyarakat melalui kegiatan penyuluhan, teknik stimulan jamban, dan pendekatan kepada warga dan para pemangku kepentingan pada wilayah desa tersebut. Berdasarkan latar belakang diatas, penulis tertarik melakukan pengabdian masyarakat di Dusun Gebang sewu melalui refungsi jamban kolam lele menjadi jamban sehat dalam rangka menuju desa bebas buang air besar 
disemarang tempat/ODF (Open Defecation Free)

TUJUAN: Tujuan pengabdian masyarakat ini adalah mengidentifikasi upaya pemberdayaan masyarakat melalui refungsi jamban kolam lele menjadi jamban sehat dalam rangka menuju desa bebas buang air besar disemarang tempat /ODF (Open Defecation Free)

METODE Metode yang digunakan adalah pemberdayaan masyarakat dengan melibatkan secara langsung masyarakat dalam setiap program yang direncanakan. Kegiatan yang direncanakan untuk mengatasi permasalahan di Dusun Gebang Sewu Meliuti: Penyuluhan, stimulan jamban sehat sederhana, pelatihan kader cilik, penetapan PERDES ODF

\section{POPULASI}

Target populasinya adalah warga Dusun Gebang Sewu Kecamatan Paron yang memiliki jamban dengan kolam lele sebanyak 42 rumah.

\section{WAKTU PELAKSANAAN}

Pengabdian masyarakat ini dilakukan pada Bulan April-Juni 2018

\section{HASIL DAN PEMBAHASAN \\ Data demografi}

Jumlah penduduk dusun Gebangsewu pada tahun 2018 adalah: 675 jiwa, dengan penduduk laki-laki sebesar 334 jiwa, perempuan 341 jiwa. Distribusi penduduk berdasarkan kelompok usia: Balita 35 orang, Anak 69 orang, Remaja 96 orang, Dewasa 347 orang, dan Lansia 128 orang. Terdapat 249 KK dan 217 soma.

\section{Pekerjaan Dan Pendapatan}

Sebagian warga bekerja sebagai petani sebanyak 217 orang, Wiraswasta 142, IRT 93, Karyawan swasta 12, Pedagang 12, TNI 1, PNS 7, Buruh tani 12, Pensiun 1, Pengangguran 12, dengan pendapatan ratarata $\mathrm{Rp}$ 500.000-Rp1.000.000

\section{Kegiatan penyuluhan tentang STOP BABs dan jamban sehat \\ Kegiatan ini bertujuan untuk meningkakan pemahaman warga tentang pentingnya penggunaan jamban sehat. Persiapan yang}

dilakukan pada kegiatan ini meliputi: koordinasi dengan perangkat desa seperti Bpk Lurah, Bpk Kasun, RT, RW dan kader untuk mensosialisasikan kegiatan penyuluhan yang akan dilakukan pada tanggal 27 April 2018. Tema dari penyuluhan ini adalah "STOP Buang Air Besar di sembarang Tempat", jumlah warga yang diundang $42 \mathrm{KK}$ dengan jamban di kolam lele. Pada kegiatan ini kami mendapatkan dukungan penuh dari perangkat dan warga, hal ini dapat dilihat dari pelaksanaan kegiatan yang kami lakukan. Warga membantu menyiapkan tempat, tikar, konsumsi (snack dan air mineral). Dukungan lain dari warga juga diperlihatkan dengan warga datang terlebih dahulu sebelum acara dimulai. Antusiasme saat warga juga tinggi, hal ini dilihat dari banyaknya pertanyaan yang diungkapkan saat penyuluhan berlangsung. Pada pelaksanaan kegiatan ini kami menggunakan metode ceramah, diskusi dan pemutaran video, tentang kebiasaan BABs. Evaluasi dari kegiatan ini adalah peningkatan pemahaman warga tentang manfaat STOP $\mathrm{BABs}$, yang dibuktikan dengan warga dapat menyebutkan kembali manfaat larangan BABs untuk kesehatan dan warga bersedia mengikuti anjuran untuk merefungsi jamban kolam lelenya menjadi jamban sehat sederhanan dengan teknik stimulan.

\section{Kegiatan pemberian stimulanjamban sehat sederhana}

Kegiatan jambanisasi merupakan salah satu upaya nyata untuk mengentaskan masalah BABs di Dusun Gebang Sewu.

Dari hasil penyuluhan yang dilakukan pada tanggal 27 April 2018, diperoleh data warga yang berkeinginan untuk membuat jamban sehat sederhana sebanyak $23 \mathrm{KK}$, sehingga untuk program jambanisasi ini diberikan pada 23 KK tersebut. Kegiatan ini dilaksanakan tanggal 29 April 2018-9 Mei 2018. Pembuatan septictang dilakukan dengan teknik gotong-royong. Pada kegiatan ini diberikan pemasangan jamban sehat sederhana pada keluarga yang masih $\mathrm{BAB}$ di kolam lele dengan teknik stimulan. Pada teknik stimulan ini pembiayaan pembuatan jamban dilakukan berdasarkan besaran dana stimulan yang tersedia dan dibantu dengan dana swadaya dari warga. Dengan demikian warga juga mempunyai keinginan berusaha untuk memiliki jamban sehat di rumahnya. 
Dana yang diperluan untuk pembuatan Satu unit septictang jamban sehat sederhana dari beton gorong-gorong sebesar Rp 350.000. Untuk membuat satu unit septictank jamban sehat sederhana warga mendapatkan stimulan sebesar Rp 180.000, dengan demikian warga harus menanggung kekurangan pembiayaan sebesar Rp 170.000.

\section{Penyuluhan cara pembibitan lele}

Kegiatan penyuluhan ini dilakukan pada tanggal 19 Mei 2018, dengan tujuan meningkatkan pemahaman warga tentang cara pembibitan lele dengan cara sehat. Pada kegiatan ini dihadiri seluruh warga yang mendapatkan stimulan jamban sehat sederhana, juga warga yang masih bertahan dengan jamban kolam lele. Jumlah audiens yang hadir $43 \mathrm{KK}$. Untuk kegiatan ini kami berkolaborasi dengan ketua kelompok petani ikan dari dusun Bendo Bapak Aminan Daroini , untuk memberikan penjelasan tentang tatacara budidaya ikan lele. Antusiasme warga sangat tinggi, hal ini dapat dilihat dari banyaknya pertanyaan yang diajukan warga saat penyuluhan berlangsung. Hasil akhir dari kegiatan ini warga mempunyai wawasan lebih tentang cara budidaya lele yang sehat. Dokumentasi kegiatan penyuluhan pembibitan lele sebagai berikut:

\section{Pelatihan kader cilik STBM}

Pelatihan kader cilik STBM ini dilaksanakan pada tanggal 10 Mei 2018, dengan tujuan meningkatkan pemahaman anak-anak dari keluarga yang memiliki jamban kolam lele. Hal ini dilakukan dengan harapan anak menjadi role model di keluarganya juga sekolahan tempat ia menuntut ilmu supaya dapat memberi contoh tentang kegiatan STBM. Pada pelatihan ini kami berikan materi 5 Pilar STBM yang didalamnya sudah mencakup kesadaran untuk tidak BABs. Metode yang digunakan dengan menggunakan audiovisual (pemutaran film tentang STBM) yang dikombinasikan dengan ceramah dan permainan. Diakhir kegiatan pelatihan ini diberikan sertifikat dan pemasangan PIN kader STBM

\section{Peresmian Perdes tentang ODF}

Di era otonomi daerah ini, Desa diberi kewenangan untuk mengatur kehidupan masyarakatnya sendiri. Untuk mencapai tujuan tersebut perlu dibuat sebuah peraturan desa (Perdes). Perdes berisi peraturan perundang-undangan yang disyahkan oleh Kepala Desa bersama badan permusyawaratan Desa. Perdes merupakan penjabaran lanjutan dari perundang-undangan yang lebih tinggi, dengan memperhatikan kepentingan sosial masyarakat setempat dan dilarang bertentangan dengan kehidupan warga setempat. Manfaat perdes sebagai pedoman kerja untuk melakukan kegiatan di Desa dan upaya pengendalian dan pengawasan. Oleh kaena itu upaya mengentaskan masalah ODF di Dusun ini perlu diperkuat dengan adanya Perdes.

\section{KESIMPULAN}

Metode pemberdayaan masyarakat dengan modifikasi teknik penyuluhan dan stimulan terbukti efektif untuk merubah perilaku warga Dusun Gebang Sewu dengan kebiasaan BAB di kolam Lele, hal ini dapat dilihat dari $23 \mathrm{KK}$ yang beralih ke Jamban sehat sederhana melalui teknik stimulan, terbentuknya Perdes dan Kader Cilik STBM.

\section{SARAN}

Diharapkan metode pemberdayaan masyarakat ini dapat diduplikasi untuk pengentasan masalah-masalah ODF ditempat lain

\section{UCAPAN TERIMAKASIH}

Ucapan terimakasih disampaikan kepada Kepala Desa Semen, kepala dusun Gebang Sewu, ibu-ibu kader dan warga Desa Semen Wilayah Puskesmas Teguhan yang telah membantu kegiatan terlaksananya program pengabdian masyarakat.

\section{DAFTAR PUSTAKA}

Bannister B, Gillespie, S. Jones, Jane. Infection:Microbiology and Management. 3rd ed. USA: Blackwell Publishing Ltd; 2006. p. 167 -200

Brooks GF, Butel,J.S, Morse,S.A. Mikrobiologi Kedokteran. 2nd ed. Jakarta: Salemba Medika; 2001.

Cairncross S, Valdmanis, V. Water Supply, Sanitation and Hygiene Promotion. In:Dean T Jamison ea, editor. Disease 
Control Priorities in Developing Countries. 2nd edition ed. Washington (DC): World Bank 2006. p. 771 -92.

Carr R. Excreta-related infections and the role of sanitation in the control of transmission. In: Bartram LFaJ, editor. Water Quality: Guidelines, Standards and Health. London: IWA Publisihing 2001 . p. $90-107$

Ditjen PP-PL. Pelaksanaan Sanitasi Total Berbasis Masyarakat Dalam Program PAMSIMAS. Jakarta: Departemen Kesehatan RI dan Pokja AMPL; 2008. p. $35-56$

Entjang I. 2000. Ilmu Kesehatan Masyarakat. Cetakan ke XIII. Bandung PT. Citra Aditya Baku

Galan ID, Kim SS, Graham JP. Exploring changes in open defecation prevalence in sub-Saharan Africa based on national level indices. BMC Public Health. 2013; 13:527.

Guyton AC. Fisiologi Kedokteran (Textbook Medical Physiology ) VI ed. Jakarta: EGC; 2006. p. $325-50$

Hindarko, S (2003). Mengolah Air Limbah Supaya Tidak Mencemari Orang Lain. Jakarta : Esha

Humphrey JH. Child undernutrition, tropical enteropathy, toilets, and handwashing. Lancet. 2009;374:1032-5

Kamal.K RC. Handbook on Community Led Total Sanitation Geneva: World Health Organization; 2008. p. 45 -62.

Kandun IN. Manual Pemberantasan Penyakit Menular. 17 ed. Jakarta: Info Medika; 2006. p. $65,180,257,84,533,645-55$.

Kementerian PPN. Laporan Pencapaian Tujuan Pembangunan Milenium di Indonesia 2010. Jakarta: Badan Perencanaan Pembangunan Nasional (BAPPENAS); 2010. p. 107

Mukherjee N. 2011, Factors Associated with Achieving and Sustaining Open Defecation Free Communities: Learning from East Java. Water and Sanitation Program. 2011:1 -8
Notoatmodjo S, 2007. Promosi Kesehatan Dan Ilmu Perilaku. Jakarta: Rineka Cipta

Pebriani R A, Dharma S, Naria E. Faktorfaktor yang berhubungan dengan penggunaan jamban keluarga dan kejadian diare di Desa Tualang Sembilar Kecamatan bambel kabupaten aceh tenggara tahun 2012. Program Sarjana Fakultas Kesehatan Masyarakat Universitas Sumatera Utara

Sarudji, 2010. Kesehatan Lingkungan. Bandung: Karya Putra Darwati

Sijbesma C, Verhagen, J. Making Urban sanitation strategies of six Indonesia cities more pro -poor and gender equitable : the case of ISSDP. IRC international Water and Sanitation Centre. 2008:4 -10.

Spears D. How much international variation in child height can open defecation explain? world bank policy research working paper number 6351. Washington DC: World Bank; 2013.

United Nations. Fact sheet on Sanitation: 2013. http://www.unwater.org/ downloads/sanitation.pdf Accessed 10 maret 2018.

Water and Sanitation Program. Economic impacts of poor sanitation in Africa: Kenya. Water and Sanitation Program. 2014 http://www.wsp.org/content/africa economic-impacts-sanitation, Kenya Accessed 2 Maret 2018.

WSP-EAP. Economic Impacts of Sanitation in Indonesia. Research Report. 2008:21-3 